REKOGNISI: Jurnal Pendidikan dan Kependidikan

ISSN 2527-5259 Vol.1, No.1, Desember 2016

\title{
HUBUNGAN KEYAKINAN ORANG TUA DENGAN SELF-EFFICACY MATEMATIS SISWA KELAS IV
}

\author{
Nurdiana Siregar \\ PGSD Universitas Nahdlatul Ulama Sumatera Utara \\ Email : nurdiana884@yahoo.co.id
}

\begin{abstract}
ABSTRAK
Penelitian ini bertujuan untuk mengetahui adakah hubungan yang signifikan antara keyakinan orang tua dengan self-efficacy matematis siswa kelas IV MIN Sihadabuan Padangsidimpuan. Metode penelitian yang digunakan adalah metode deskriptif dengan pendekatan korelasi. Instrumen yang digunakan untuk kedua variabel adalah skala self-efficacy untuk melihat selfefficacy matematis siswa dan angket untuk melihat keyakinan orang tua. Skala self-efficacy meтuat 20 pernyataan sedangkan angket keyakinan orang tua memuat 10 pernyataan, masingmasing nontes tersebut memuat empat alternatif jawaban. Sampel penelitian ini berjumlah 94 siswa dari kelas IV MIN Sihadabuan Padangsidimpuan. Data yang diperoleh dianalisis dengan Pearson dilanjutkan dengan uji-t, sebelumnya telah diperoleh bahwa data self-efficacy siswa berdistribusi normal yaitu 0,08 > 0,05 dan data angket orang tua juga berdistribusi normal yaitu 0,06 >0,05. Linearitas dipenuhi yaitu 0,00 <0,05. Hasil perhitungan diperoleh $t_{\text {hitung }}=$ 16,14 sedangkan $t_{\text {tabel }}=1$,99. Jadi $t_{\text {hitung }}>t_{\text {tabel }}$ yaitu 16,14 $>1,99$ atau 0,000 $<0,05$, artinya Ho ditolak. Hal tersebut menunjukkan bahwa terdapat hubungan yang signifikan antara keyakinan orang tua dengan self-efficacy matematis siswa kelas IV Di MIN Sihadabuan Padangsidimpuan.
\end{abstract}

Kata kunci: keyakinan orang tua, self-efficacy matematis siswa 


\begin{abstract}
This study aims to determine is there a significant relationship between parental beliefs with self-efficacy mathematical of fourth grade students at MIN Sihadabuan Padangsidimpuan. The method used descriptive method of correlation. Instruments are used for both variables are selfefficacy scale to see mathematical self-efficacy questionnaire of students and the evestionaire to see the parents' belief. The scale of self-efficacy questionnaire contains 20 statements while parents'confidence holds up to 10 statements, each nontest contains four alternative answer. The research sample contains 94 students of fourth grade at MIN Sihadabuan Padangsidimpuan. Data were analyzed with Pearson continued with t-test, had earlier found that students' self-efficacy data is normally distributed is 0,08>0,05 and a parents, questionnaire data also normal distribution is 0,06 >0,05. Linearity is filled namely 0,00< 0,05 . The result of the calculation, $t_{\text {arithmetic }}=16,14$ whereas $t_{\text {tabel }}=1,99$. So $t_{\text {arithmetic }}>t_{\text {table }}$ is 16,14 $>1,99$ or 0,000 <0,05, which means that Ho is rejected. It shows that there is a significant relationship between parental beliefs with self-efficacy mathematical of fourth grade students at MIN Sihadabuan Padangsidimpuan.
\end{abstract}

Key words: parents' belief, self-efficacy mathematical students

\title{
PENDAHULUAN
}

Faktor kognisi merupakan salah satu faktor yang mempengaruhi perilaku siswa dalam belajar. Seperti halnya teori kognitif sosial Bandura (Santrock, 2013: 284) yaitu faktor kognitif memainkan peran penting dalam pembelajaran, yang salah satunya mengenai keyakinan.

Dalam Permendiknas Nomor 22 tahun 2006 Tentang Standar Isi, dijelaskan bahwa salah satu tujuan pembelajaran matematika adalah agar siswa memiliki sikap menghargai kegunaan matematika dalam kehidupan yakni salah satunya siswa percaya diri dalam pemecahan masalah. Di samping itu, Standar Kompetensi Lulusan mata pelajaran matematika Sekolah Dasar/Madrasah Ibtidaiyah salah satunya adalah memiliki sikap menghargai kegunaan matematika dalam kehidupan.

Ketidakyakinan siswa di bidang matematika dapat dilihat dari responnya ketika melakukan pekerjaan matematika. Hasil studi pendahuluan di MIN Sihadabuan Padangsidimpuan, berupa kegiatan wawancara terhadap guru MIN Sihadabuan, adanya kebiasaan siswa mencontek ketika ujian, pada saat diberikan kesempatan untuk bertanya siswa lebih banyak diam, dan menunjukkan rasa takut dan malu ketika diminta menyelesaikan soal matematika ke depan kelas.

Fenomena di atas, mengindikasikasikan bahwa siswa memiliki keyakinan diri yang rendah terhadap kemampuannya dalam bidang matematika. Sejalan dengan yang dikemukakan Woolfolk (2009: 152) bahwa siswa dengan efikasi akademik rendah lebih banyak yang menyontek. Begitu juga dengan Stuart (Hannula et al, 2005: 38) menyatakan the lack of self-confidence can lead to 
mathematics anxiety that can be seen as a fear to become embarrassed and as avoidance behaviour during mathematics lessons, yang maknanya kurangnya rasa percaya diri dapat menyebabkan kecemasan matematika yang dapat dilihat sebagai takut menjadi malu dan perilaku penghindaran selama pelajaran matematika.

Kepercayaan diri siswa dalam matematika merupakan salah satu perhatian dari Trends in International Mathematics and Science Study (TIMSS). Melihat kepercayaan diri siswa dalam matematika, dilakukan dengan mengajukan 9 pernyataan dengan masing-masing empat alternatif jawaban. Hasil evaluasi TIMSS 2011 untuk kepercayaan diri siswa terhadap matematika, dari 50 negara, 34\% siswa yang confident, $46 \%$ siswa somewhat confident, dan $21 \%$ siswa not confident. Kepercayaan diri siswa kelas VIII terhadap matematika, Indonesia hanya memiliki $3 \%$ siswa yang confident, $52 \%$ siswa somewhat confident, dan $45 \%$ siswa not confident.

Keyakinan terhadap kemampuan diri dalam suatu bidang disebut selfeffikasi. Bandura (dalam Woolfolk, 2009: 219) menyatakan bahwa efikasi-diri adalah keyakinan seseorang akan kapabilitasnya untuk mengorganisasikan dan melaksanakan rangkaian tindakan yang dibutuhkan untuk mencapai tujuan. Jadi efikasi-diri di bidang matematika dapat disebut self-efficacy matematis.

Woolfolk (2009: 219) menyatakan orang dengan efikasi-diri yang kuat untuk tugas tertentu misalnya "Aku bagus di matematika" cenderung mengatribusikan kegagalan mereka pada kurangnya usaha dan sebaliknya, orang dengan efikasi-diri yang rendah, misalnya "Aku payah di matematika" cenderung mengatribusikan kegagalannya pada kurangnya kemampuan. Dengan kata lain, siswa yang memiliki efikasi-diri matematis yang tinggi akan memiliki pandangan positif terhadap apapun hasil yang diperoleh.

Margono (2005: 4) menyatakan terbentuknya rasa percaya diri terhadap matematika merupakan proses yang kompleks termasuk interaksinya dengan beberapa faktor diantaranya adalah keluarga, sosialisasi, pengalaman di sekolah, hubungan dengan aturan dan budaya. Lebih lanjut lagi, Margono (2005: 5) menyatakan bahwa kepercayaan diri siswa terhadap matematika dapat dibagi dalam tiga komponen yaitu: (1) kepercayaan terhadap pemahaman dan kesadaran diri terhadap kemampuan matematikanya, (2) kemampuan untuk menentukan secara realistik sasaran yang ingin dicapai dan menyusun rencana aksi sebagai usaha meraih sasaran, serta (3) kepercayaan terhadap matematika itu sendiri.

Anak di usia SD/MI sehari-harinya menghabiskan waktunya di sekolah, di rumah dan di luar rumah untuk berkunjung dan berosialisasi dengan sebayanya. Rumah dan anggota keluarga adalah bagian yang penting dari kehidupan anak. Wade dan Carol (2008: 215) menyatakan bahwa orang tua mempengaruhi anakanaknya dalam berbagai hal, yang salah satunya efikasi-diri. Begitu juga halnya dengan Papalia dan Ruth (2014: 353) menya-takan bahwa orang tua sangat kuat mempengaruhi keyakinan anak terha-dap kompetensinya. Hasil studi longitudinal 
Fredricks dan Eccles (dalam Papalia dan Ruth, 2014: 353) terhadap 514 anak dari keluarga kelas menengah di Amerika Serikat menyatakan bahwa orang tua yang yakin akan kompetensi anak mereka dalam matematika berasosiasi sangat kuat dengan keyakinan anak.

Wade dan Carol (2008: 215) menyatakan orang tua adalah agen pengubah yang membantu anak berubah haluan ke arah yang lebih sehat, dengan selalu melakukan pengawasan dan memastikan bahwa mereka rajin bersekolah dan memberikan nilai-nilai kedisiplinan yang konsisten. Anak yang belajar dengan giat dan memperoleh nilai bagus serta pujian dari orang tuanya akan beranggapan bahwa kerja keras disegala situasi juga akan memberikan hasil yang memuaskan. Sebaliknya, bila anak yang giat belajar dan mendapatkan nilai buruk dan diabaikan oleh orangtua, akan belajar bahwa bekerja keras tidak ada gunanya. Wade dan Carol (2008: 215) menegaskan penting orang tua untuk memiliki kualitas hubungan dengan anak, sehingga anak merasa disayangi, dijaga, dan dihargai.

Mueller dan Dweck (dalam Wade dan Carol, 2008: 178) melakukan sejumlah penelitian terhadap anak-anak, menyatakan bahwa faktor utama yang mempengaruhi pemilihan jenis tujuan pada anak-anak adalah masukan dari orang tua berupa pujian atas inteligensi alami anak tersebut, seperti nilaimu bagus, kamu memang anak yang cerdas. Dengan kata lain, apabila penghargaan untuk anak tersebut besar, maka akan meningkatkan kepercayaan diri anak.

Adicondro dan Alfi (2011: 20) menyatakan bahwa penghargaan merupakan salah satu aspek dari dukungan sosial, di samping dukungan emosional, instrumental, dan informatif. Baron dan Byrne (2004: 50) menyatakan bahwa dukungan sosial adalah kenyamanan secara fisik \& psikologis yang diberikan oleh teman atau anggota keluarga. Oleh karena itu, untuk memahami anak berkaitan dengan efikasi diri siswa di bidang matematika, perlu melihat lingkungan keluarga khususnya pengaruh keyakinan orang tua.

Di samping itu, Papalia dan Ruth (2014: 150) menyatakan ada enam pendekatan dalam mempelajari perkembangan kognitif siswa, salah satunya pendekatan konteks sosial. Papalia dan Ruth (2014: 151) menyatakan pendekatan konteks sosial adalah pendekatan yang berokus pada pengaruh lingkungan khususnya orang tua dan pengasuh lainnya terhadap proses belajar.

Berdasarkan pemaparan di atas, rumusan masalah dalam penelitian ini adalah Apakah terdapat hubungan yang signifikan antara keyakinan orang tua dengan self-efficacy matematis siswa kelas IV MIN Sihadabuan Padangsidimpuan? Sejalan dengan rumusan masalah tersebut, penelitian ini bertujuan untuk mengetahui dengan jelas hubungan (signifikan) antara keyakinan orang tua dengan self-efficacy matematis siswa kelas IV MIN Sihadabuan Padangsidimpuan. 


\section{METODE PENELITIAN}

Penelitian ini menggunakan metode deskriptif dengan pendekatan korelasi. Variabel penelitian ada dua jenis yaitu variabel bebas $(\mathrm{X})$ dan variabel terikat $(\mathrm{Y})$. Variabel bebas adalah keyakinan orang tua, sedangkan variabel terikatnya adalah self-efficacy matematis siswa.

Populasi dalam penelitian ini adalah seluruh siswa kelas IV MIN Sihadabuan Padangsidimpuan sebanyak 94 orang. Namun, mengingat jumlah populasi di bawah 100 orang, maka sampelnya merupakan populasinya. Dengan kata lain, jumlah sampelnya sebanyak 94 orang.

Instrumen yang digunakan dalam penelitian ini adalah nontes, angket keyakinan orang tua terdiri dari 10 pernyataan dengan empat alternatif jawaban sedangkan skala self-efficacy terdiri dari 20 butir pernyataan yang mencakup 10 pernyataan positif dan 10 pernyataan negatif dengan masing-masing empat alternatif jawaban. Skala self-efficacy di kembangkan sesuai dengan 3 komponen kepercayaan diri yang dikemukakan Margono.

Data angket keyakinan orang tua dan skala efikasi-diri matematis siswa digolongkan dalam 3 kategori diagnosis. Dalam pengelompokan tersebut diperlukan $\mu, \mu$ adalah mean teoritis. $\mu$ untuk data keyakinan orang tua sebesar 25 sedangkan $\mu$ untuk data efikasi-diri matematis siswa sebesar 50. Adapun kategori skor keyakinan orang tua dan efikasi-diri siswa dikelompokkan dengan ketentuan sebagai berikut:

$$
\begin{aligned}
X<(\mu-1,0 \sigma) & \text { rendah } \\
(\mu-1,0 \sigma) \leq X<(\mu+1,0 \sigma) & \text { sedang } \\
(\mu+1,0 \sigma) \leq X & \text { tinggi }
\end{aligned}
$$

Kedua data tersebut lebih lanjut lagi dianalisis secara statistik inferensial, untuk melihat normalitas data dan linearitas regresi. Tahap selanjutnya kedua data tersebut dianalisis dengan menghitung koefisien korelasi dengan menggunakan korelasi product moment. Nilai statistik ketiga uji tersebut diperoleh dengan menggunakan aplikasi SPSS 21.

Pengujian lanjutan yaitu uji signifikansi hubungan fariabel $\mathrm{X}$ dengan $\mathrm{Y}$ menggunakan rumus Uji-t. Kaidah pengujian sebagai berikut:

Jika $t_{\text {hitung }}<t_{\text {tabel }}$, maka Ho diterima

Jika $t_{\text {hitung }}>t_{\text {tabel }}$, maka Ho ditolak. 


\section{HASIL DAN PEMBAHASAN}

\section{Keyakinan Orang Tua}

Data yang telah terkumpul dan setelah pengolahan data angket keyakinan orang tua terhadap kemampuan matematika siswa kelas IV MIN Sihadabuan Padangsidimpuan, skor yang diperoleh menyebar dari skor yang terendah adalah 17 dan skor tertinggi 40, sedangkan skor yang mungkin diperoleh siswa adalah 10 sampai 40.

Statistik deskiptif untuk data keyakinan orang tua terhadap kemampuan matematika anak yang dihitung adalah rerata dan standar deviasinya. Adapun rerata keyakinan orang tua terhadap kemampuan anak dalam matematika sebesar 28 sedangkan standar deviasinya sebesar 5,73.

Penyebaran data tersebut dikelompokkan ke dalam tiga kategori diagnosis tingkat keyakinan orang tua terhadap kemampuan anak dalam bidang matematika seperti yang telah dijelaskan sebelumnya. Kategori tersebut adalah rendah, sedang, dan tinggi. Adapun pengelompokkannya dapat dilihat pada tabel 1.

Tabel 1 tersebut menunjukkan bahwa kebanyakan orang tua yang yakin dengan kemampuan anaknya dalam bidang matematika berada pada kategori sedang. Tingkat keyakinan orang tua terhadap kemampuan anak pada kategori rendah ada 4 orang dari 94 orang.

\section{Self-Efficacy Matematis}

Data yang telah terkumpul dilanjutkan dengan pengolahan data. Skor selfefficacy matematis siswa bervariasi, skor terendah 35 dan skor yang tertinggi 80.

Statistik deskiptif untuk data efikasi-diri matematis siswa yang dihitung adalah rerata dan standar deviasinya. Adapun rerata efikasi-diri siswa di bidang matematika sebesar 58 yang artinya berada pada kategori sedang dengan standar deviasinya sebesar 9,58.

Data efikasi-diri siswa di bidang matematika dikelompokkan menjadi tiga kategori seperti yang telah dijelaskan sebelumnya. Adapun pengelompokkannya dapat dilihat pada tabel 2 .

Tabel 2 tersebut menunjukkan bahwa rata-rata siswa memiliki efikasi-diri di bidang matematika berada pada tingkat sedang. Siswa yang memiliki efikasi-diri matematis tingkat rendah, ada 3 siswa dari 94 siswa. 
Tabel 1. Kategori Tingkat Keyakinan Orang Tua siswa

\begin{tabular}{|l|c|c|c|}
\hline Kategori & $\begin{array}{c}\text { Rentang } \\
\text { Skor }\end{array}$ & $\mathbf{f}$ & $\mathbf{\%}$ \\
\hline Tinggi & $30-40$ & 35 & 37 \\
\hline Sedang & $20-29$ & 55 & 59 \\
\hline Rendah & $10-19$ & 4 & 4 \\
\hline
\end{tabular}

Tabel 2. Kategori Tingkat Efikasi-diri Matematis Siswa

\begin{tabular}{|l|c|c|c|}
\hline \multicolumn{1}{|c|}{ Kategori } & $\begin{array}{c}\text { Rentang } \\
\text { Skor }\end{array}$ & f & \% \\
\hline Tinggi & $60-80$ & 37 & 39 \\
\hline Sedang & $40-59$ & 54 & 58 \\
\hline Rendah & $20-39$ & 3 & 3 \\
\hline
\end{tabular}

\section{Hasil Analisis Korelasi X dengan Y}

Keterkaitan dua variabel secara deskriptif dapat dilihat berdasarkan rerata skor keyakinan orang tua dan rerata efikasi-diri matemati siswa. Hasil penelitian keyakinan orang tua menunjukkan rerata skor berada pada tingkat keyakinan sedang dan rerata skor efikasi-diri siswa dibidang matematika juga menunjukkan tingkat keyakinan sedang. Begitu juga halnya dengan persentase keyakinan orang tua terhadap kemampuan matematika anak dan efikasi-diri matematis siswa pada masing-masing kategori diagnosis tingkat keyakinan. Persentase dari kedua data tersebut disajikan dalam bentuk diagram batang, seperti gambar 1 berikut,

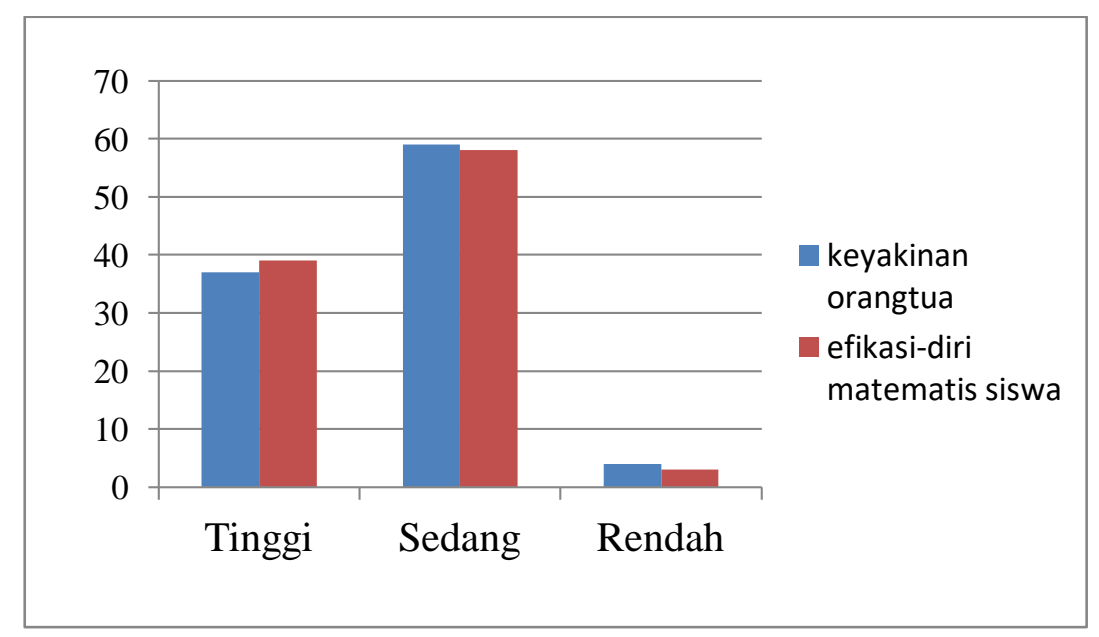

\section{Gambar 1. Persentase Keyakinan Orang Tua dan Self-Efficacy} Matematis Siswa 
Gambar 1 tersebut menunjukkan bahwa banyak orang tua yang yakin akan kemampuan anaknya di bidang matematika dengan efikasi-diri siswa pada tingkat tinggi hanya selisih dua, sedangkan pada kategori sedang memiliki selisih satu, dan kategori rendah memiliki selisih satu. Hal tersebut menunjukkan bahwa jika orang tua yang yakin akan kemampuan anak di bidang matematika berada pada kategori tinggi maka efikasi-diri matematis siswa juga tinggi. Begitu juga halnya untuk efikasi-diri matematis siswa pada tingkat sedang dan rendah.

Kedua data tersebut dianalisis lebih lanjut secara statistik inferensial. Besar koefisisien korelasi keyakinan orang tua dengan efikasi-diri siswa di bidang matematika yang diperoleh dengan rumus korelasi product moment menggunakan aplikasi SPSS 21 adalah sebesar 0,858. Nilai $r_{x y}$ tersebut dianalisis lanjut dengan uji$\mathrm{t}$, diperoleh $\mathrm{t}_{\text {hitung }}=16,14$. Taraf signifikansi 0,05 uji satu pihak dan $\mathrm{dk}=92$ diperoleh $t_{\text {tabel }}=1,99$. Dengan merujuk pada kriteria pengujian yang telah dijelaskan sebelumnya, maka $t_{\text {hitung }}>t_{\text {tabel }}$ yaitu 16,14 $>1,99$ atau sig $<\alpha$ yaitu $0,000<0,05$. Ini menunjukkan bahwa Hipotesis nol ditolak, artinya terdapat hubungan yang signifikan antara keyakinan orang tua dengan efikasi-diri matematis siswa kelas IV MIN Sihadabuan Padangsidimpuan.

Keyakinan orang tua merupakan salah satu faktor pendukung disamping faktor lainnya dalam menentukan efikasi-diri siswa dibidang matematika. Orang tua memberikan dukungan sosial bagi anaknya baik dukungan emosi, penghargaan, instrumen maupun informatif.

Orang tua yang mengawasi dan memperhatikan perkembangan kognitif anak berdasarkan hasil ujian matematika akan memberikan penilaian pada anak, apakah baik di bidang matematika atau tidak. Dukungan orang tua berupa penghargaan yaitu pujian atas prestasi atau hasil ujian siswa merupakan penguat bagi siswa untuk lebih giat lagi dalam belajar matematika baik di rumah maupun di sekolah. Oleh karena itu, orangtua mesti membangun hubungan yang berkualitas ketika bersama anak, dengan begitu anak akan merasa disayangi, diperhatikan, dan dijaga. Suasana tersebut akan membuat anak nyaman belajar matematika ketika di rumah.

Dukungan sosial orang tua berupa dukungan emosi akan mempengaruhi efikasi-diri siswa, baik kepercayaan terhadap pemahaman dan kesadaran diri terhadap kemampuan matematikanya, kemampuan untuk menentukan yang ingin dicapai dan menyusun rencana aksi sebagai usaha meraih sasaran, dan kepercayaan terhadap matematika itu sendiri. Indikator-indikator tersebut dapat memberikan gambaran sebagai berikut, siswa yang memiliki efikasi-diri akan lebih giat belajar matematika meskipun ia mengalami kegagalan atau nilai ujian matematika yang rendah, karena ingin mendapat pujian dan penghargaan dari orang tua. Bahkan siswa tersebut akan belajar lebih giat lagi, karena Ia menganggap kegagalan itu dikarenakan hanya kurang usaha. 
Berdasarkan temuan penelitian ini bahwa dukungan emosi merupakan kebutuhan yang perlu dipenuhi orang tua terhadap anak, agar siswa lebih yakin akan kemampuannya di bidang matematika sehingga siswa tersebut lebih giat belajar matematika baik di sekolah maupun di rumah. Dapat pula dikatakan, bahwa dukungan sosial dari orang tua berupa keyakinan orang tua terhadap kemampuan anak sebagai energi untuk membangkitkan dorongan dalam diri bagi siswa untuk lebih giat belajar matematika.

\section{SIMPULAN}

Berdasarkan hasil penelitian dan pembahasan yang telah dijelaskan sebelumnya, dapat disimpulkan bahwa terdapat hubungan yang signifikan antara keyakinan orang tua dengan efikasi-diri siswa pada bidang matematika di kelas IV MIN Sihadabuan Padangsidimpuan. Efikasi diri siswa di bidang matematika merupakan hasil dukungan emosi orang tua berupa keyakinan orang tua terhadap kemampuan anak di bidang matematika. 


\section{DAFTAR PUSTAKA}

Adicondro, N. dan Alfi Purnamasari, 2011. Efikasi Diri, Dukungan Sosial Keluarga dan SelfRegulated Learning Pada Siswa Kelas VIII. Jurnal Humanitas, Volume VIII, No.1: 17-27.

Baron, R. A. dan Donn B. Tanpa tahun. Psikologi Sosial. Terjemahan oleh: Ratna Djuwita, dkk. 2004. Jakarta: Erlangga.

Hannula et al, 2005. Gender Comparisons of Pupils Self-Confidence In Mathematics Learning. Nordic Studies in Mathematics Education No. 3-4, (Online), (http: //studentportalen.uu.se/.../download.action?..., diakses 28 Januari 2015).

Margono, G. 2005. Pengembangan Instrumen Rasa Percaya Diri Mahasiswa Terhadap Matematika. Jurnal Ilmu Pendidikan, Jilid 12 No. 1: 1-18.

Papalia, D.E. dan Ruth D. F. Tanpa tahun. Menyelami Perkembangan Manusia. Terjemahan oleh: Fitriani W.H. 2014. Jakarta: Salemba Humanika.

Santrock, Jhon W. Tanpa tahun. Psikologi Pendidikan. Terjemahan oleh: Wibowo. 2013. Jakarta: Kencana.

TIMSS. 2011. TIMSS 2011 International Result In Mathematics. Chestnut Hill: TIMSS dan PIRLS International Study Center, (Online), (http: //timssandpirls.bc.edu/timss2011/international-result-math, di akses 6 Januari 2014).

Wade, C dan Carol T. Tanpa tahun. Psikologi Jilid 2. Terjemahan oleh: Padang M. Dan Dinastuti. 2008. Jakarta: Erlangga.

Woolfolk, A. Tanpa tahun. Educational Psychology Active Learning Edition Bagian Pertama. Terjemahan oleh: Soetjipto. 2009. Yogyakarta: Pustaka Pelajar. 